Purdue University

Purdue e-Pubs

Charleston Library Conference

\title{
Return on Investment: New Strategies for Marketing Digital Resources to Academic Faculty and Students From Three Perspectives: Publisher, Collection Development, and Research Services
}

\author{
Elyse L. Profera \\ Taylor \& Francis Group, elyse.profera@taylorandfrancis.com \\ Michael A. Arthur \\ University of Central Florida, maarthur@ua.edu \\ Barbara G. Tierney \\ University of Central Florida, barbara.tierney@ucf.edu
}

Follow this and additional works at: https://docs.lib.purdue.edu/charleston

Part of the Library and Information Science Commons

An indexed, print copy of the Proceedings is also available for purchase at:

http://www.thepress.purdue.edu/series/charleston.

You may also be interested in the new series, Charleston Insights in Library, Archival, and Information Sciences. Find out more at: http://www.thepress.purdue.edu/series/charleston-insights-library-archivaland-information-sciences.

Elyse L. Profera, Michael A. Arthur, and Barbara G. Tierney, "Return on Investment: New Strategies for Marketing Digital Resources to Academic Faculty and Students From Three Perspectives: Publisher, Collection Development, and Research Services" (2014). Proceedings of the Charleston Library Conference.

http://dx.doi.org/10.5703/1288284315586

This document has been made available through Purdue e-Pubs, a service of the Purdue University Libraries. Please contact epubs@purdue.edu for additional information. 


\title{
Return on Investment: New Strategies for Marketing Digital Resources to Academic Faculty and Students From Three Perspectives: Publisher, Collection Development, and Research Services
}

\author{
Elyse Profera, Regional Sales Manager, Central U.S. Taylor \& Francis Group \\ Michael A. Arthur, Head of Acquisitions and Collection Services, University of Central Florida Libraries \\ Barbara G. Tierney, Head of Research and Information Services, University of Central Florida Libraries
}

\begin{abstract}
Game-changing strategies for marketing digital resources to end users are crucial for establishing return on investment in this period of reduced library collection budgets and challenging resource prices. When expensive digital resources are purchased by academic libraries, there needs to be a marketing plan in place for getting these resources into the hands of end users as quickly as possible.

One strategy for success is a marketing collaboration between the publisher and the academic library. The Profera, Arthur, Tierney 2014 Charleston Conference presentation on this topic focused on the success achieved at the University of Central Florida Libraries where such a collaboration included experts from Taylor \& Francis working closely with the Head of Acquisitions \& Collection Services and the Head of Research Services. Together they sponsored a digital resources educational workshop that included presentations by faculty, librarians, and Taylor \& Francis representatives and reached out to end users as well as librarians from several Florida institutions. The UCF Libraries has also partnered with publishers to promote resources through various events sponsored by publishers and aimed at librarians and faculty from UCF and surrounding institutions.
\end{abstract}

The presenters covered innovative strategies for marketing digital resources including hosting vendor presentations and trainings in library classrooms or at academic faculty workshops and hosting webinars and presentations. With the focus on marketing to end users, the presenters concentrated on ways that academic faculty and librarians have been included in training and outreach related to new products or major enhancements to existing library resources.

\section{Taylor \& Francis Perspective}

Taylor \& Francis (T\&F) rolled out a new initiative in 2014 to host collaborative library-publisheracademic workshops in key areas across the Americas with the intent of fostering relationships and goodwill in the library and academic community. Recent primary research conducted by $T \& F$ to the library community cites that $77 \%$ of librarians agree that interactive workshops are the number one activity publishers can do to raise awareness of their content.

Taylor \& Francis and the University of Central Florida (UCF) collaborated on one of these workshops that was held in February 2014. The workshop raised the profile of both Taylor \& Francis and the University of Central Florida across the state and this workshop was the foundation of a partnership that continued throughout 2014. UCF is a partner with one of the largest commercial publishers in the world. The success of this workshop emphasizes the importance of human-to-human communication and the impact it can have with publisher-library relations and marketing outreach to end users.

\section{Facilitating Relationships}

In 2014, Taylor \& Francis conducted research on how to personalize library service to improve scholarly communication; the results were then presented at the 2014 NASIG conference. When asked what publishers can do to work with institutions to raise awareness about their 
content, survey respondents provided the following top five tactics:

1. Publisher-library workshops (77\%).

2. Quarterly newsletters by subject (73\%).

3. Free access months (65\%).

4. Print and e-promotional items for library distribution (61\%).

5. Email campaigns to end users at (45\%).

Human-to-human communication has been a highly effective way to nurture existing relationships and cultivate new partnerships, and that has been the focus of T\&F outreach in 2014. T\&F has been engaging nonstop with customers, and working alongside regional sales teams to help drive results and return on investment for libraries. Successful initiatives included the hosting of workshops in the US, roadshows in India, author talks in China, one-on-one visits to customers in the US, and conducting country tours in South America to roll out Taylor \& Francis Online (TFO) platform training. Throughout this work, people began to associate T\&F with the humans that represent the company, and the excellent outreach fostered a sense that professional and personal connections have a profound impact on engaging with the market. Human-to-human communication reinforces the notion of developing your own personal brand. Because of the outreach efforts of Ms. Profera and others at T\&F, librarians at UCF now automatically associate her as the representative and face of the company and this establishes a strong bond. This bond and name recognition is important for the publisher and the library because with it comes trust and reliance as each of the partners invests in the other with the overall goal being to provide users with the best content and experience while also focusing on return on investment.

\section{Raising the Bar}

During her time as Library Communications Manager, Ms. Profera has continually sought new ways to help T\&F stand out in the marketplace and differentiate itself from the competition. She advocates for the T\&F brand and communicates to the library community that T\&F wants to hear what librarians have to say. T\&F wants to be part of the conversation with a focus on brand loyalty and a lasting positive impression. Toward this aim, Ms. Profera decided to implement a plan for library-publisher workshops across the US and Latin America to help raise the profile of the company, and to establish a presence with information professionals that did not previously exist. The UCF workshop set the tone for how T\&F would make their mark with future library workshops. Ms. Profera hosted four workshops in 2014 before transitioning to a new role with T\&F.

\section{Planning a Workshop from Start to Finish}

Ms. Profera outlined nine key steps to rolling out and hosting a successful workshop event: research/concept; planning, budget, and control; resources and allies; production of collaterals; marketing and promotions; sales and registrations; logistics/administration; on-site management; and post-event review. She described the process of planning the successful two-day UCF workshop event in a case study.

Prior to the event, Michael Arthur, Elyse Profera, and the US sales team for T\&F worked diligently to pull together a list of invitees that they wanted to attend the workshop. At the time, T\&F was in the process of finalizing a sales deal with the Florida Virtual Library Campus and 19 of its institutions. Mr. Arthur extended T\&F's efforts by sending invitations to various statewide groups that included members from the state universities, state colleges, and independent colleges and universities of Florida. Mr. Arthur and T\&F worked together to establish a compelling two-day agenda. Ms. Profera developed a business plan for the event, set a budget, secured UCF as a key location, and leveraged relationships both externally and internally across T\&F's editorial and sales departments. Additionally, she developed presentations, event kits, name tags, a registration list, thank you gifts, and reports.

\section{T\&F/UCF Workshop: Panels, Presentations, and Usage}

It is important to note that the T\&F/UCF workshop was not a sales pitch; rather, this was a two-way 
dialogue where publishers and librarians came together to discuss and listen to library-centric topics.

The first day of events consisted of partnering with an academic, Dr. Rosalind Beiler (Director of Public History and Associate Professor of History, University of Central Florida) to present on classroom teaching with a digital primary source archive and how the resource was integrated into her curriculum and syllabus; an eight-person Subject Librarian panel discussion in which UCF Subject Librarians discussed how they conducted their own marketing efforts to reach academic faculty and end users; and a panel on open access in which topics like discoverability of free content and its permanence were discussed.

The second day of events included an in-depth look at usage for not only UCF but also the state of Florida, as well as a workshop conducted by T\&F's new Library Communications Manager, Stacy Sieck, regarding "Tips on How to Get Published and the Peer Review Process." The indepth usage analysis for UCF led T\&F's research and business intelligence team to develop a global tool to streamline ways for future reporting and analytics to be developed for future events and customer visits.

This workshop was the start of a mutually beneficial relationship for the UCF Libraries and Taylor \& Francis. In July, Mr. Arthur visited the T\&F office for a tour and to cohost a focus group on T\&F's newest white paper, "Social Media in the Use of Libraries." In addition, T\&F and UCF worked together to present "Return on Investment: New Strategies for Marketing Digital Resources" for the 2014 Charleston Conference. Most recently, T\&F representatives, including Ms. Profera, visited the UCF campus to speak on T\&F's research in the open access marketplace. This workshop allowed Ms. Profera to benchmark other workshops that T\&F hosted at Loyola Marymount University (LMU) and the International Spy Museum, as well as a different approach in Santiago, Chile, where the company explored the concept of delivering the workshop to the customer in April 2014. At the LMU workshop, Jeffra Bussmann (STEM/Web Librarian at CSU East Bay) spoke on transforming knowledge with research justice. Most recently, at the International Spy Museum event, Syracuse University's Annie Rauh (Engineering Librarian) spoke on an OA research project that Cornell and Syracuse Libraries embarked on together.

The aforementioned initiatives speak to the value and success T\&F has achieved from working together with the library community to build trust and camaraderie. These efforts have helped set T\&F apart from other large commercial publishing organizations by taking a friendly, yet professional, approach to engaging with the library market.

\section{The UCF Perspective}

The expectations for marketing to end users and improving usage through active partnership with publishers increased dramatically in 2014 as a result of the collaborative efforts with T\&F and other major publishers. Subject Librarians and Acquisitions and Collection Services have always been focused on alerting users to new resources and training end users. However, the start of a new Subject Librarian model in 2013 resulted in a new emphasis on the public face of the library and greater expectations for librarians to be actively engaged in the disciplines they represent.

The Head of Acquisitions \& Collection

Development has now established a high priority for marketing new and existing products and has focused heavily on arranging training for Subject Lbrarians. Building on existing relationships with publishers and vendors has proven advantageous for UCF and several publishers have been eager to provide training and marketing assistance. The initial workshop jointly hosted by T\&F and UCF definitely raised the bar for future events and at the time of the 2014 Charleston Conference presentation more plans are in place for UCF to host similar events.

The Head of Acquisitions and Collection Services hired a new assistant with an academic background and interest in marketing. Her assistance and collaboration throughout the early part of 2014 helped in the development of new goals in the area of marketing library resources. Librarians working in Acquisitions and Collections 
Services are encouraged to seek out partnerships with public services librarians, teaching faculty and interested units on campus as a way of marketing library resources and gaining valuable insight into the needs of faculty and students.

Efforts at UCF to increase awareness of new library resources and improvements or updates to existing resources include:

- Refinement of the Collection Development website.

- Collaboration with the UCF Faculty Center for Teaching and Learning, resulting in weekly email blasts to all UCF faculty, and regular articles in Faculty Focus, the quarterly newsletter for UCF.

- Regular marketing of digital resources on the mastheads of the library home page and Scholarly Communication web page, as well as through digital signage in the library.

- Hosting webinars and presentations (for both academic faculty and librarians) that focus on exciting new products or major enhancements to existing library resources.

- Hosting vendor presentations and trainings in library classrooms or at academic faculty workshops.

\section{The Role of Subject Librarians in Marketing to End Users}

The University of Central Florida Libraries has 15 Subject Librarians (http://library.ucf.edu /SubjectLibrarians/) who are encouraged to engage in proactive outreach to their assigned academic programs, faculty and students. UCF Libraries believes that the Subject Librarians are excellent conduits for connecting end users with library resources.

The Subject Librarians market UCF Libraries' resources via e-newsletters, customized webbased research guides, library instruction sessions, and presentations at academic department and university-wide meetings and workshops. For example, when T\&F sponsored the workshop on digital resources that was attended by both academic librarians and faculty at the main UCF Orlando campus in spring 2014, the UCF Subject Librarians presented a panel program which focused on innovative outreach strategies for marketing library resources to UCF constituencies.

UCF Subject Librarians reach out to their assigned academic departments and faculty through regular librarian-authored e-newsletters that are sent out at the beginning of each semester. What messages are the Subject Librarians sending to their academic departments and faculty? Often the Subject Librarians are updating faculty regarding major library purchases of new digital resources. These messages are developed and disseminated after collaboration between public and technical services librarians in a positive partnership that continues to benefit the UCF community. Below is a sample of articles which UCF Subject Librarians used in their Fall 2014 Newsletters:

\section{Streaming Videos}

"We currently have three streaming video services available. Here's an overview:

Alexander Street Press includes thousands of titles in 12 subject collections; FMG Films on Demand mostly provides films for the Humanities and Sciences and offers more than 130 titles; Swank's Digital Campus provides a collection of over 19,000 theatrical films and television programs available to embed in webcourses."

\section{Springer eBooks}

"Springer is a major publisher of academic and professional books and book series. Their eBooks are suitable for research, study, and course projects, and can be assigned as textbooks. The UCF Library has perpetual rights and online access to Springer books published in English between 2005 and 2014, comprising over 16,000 volumes. In addition, UCF users have access to all of Springer's major book series (from 1997 to 2014) including the well-known Lecture Notes Series. Springer eBooks are available to all UCF students, faculty and staff anywhere, anytime. Because Springer eBooks are in PDF format, students can print, e-mail, and download entire chapters and 
books to read off-line on a cell phone, eBook reader (such as Kindle), laptop, or any computer."

\section{The Important Role LibGuides Play in Marketing Library Resources}

LibGuides are an important tool for providing basic instruction and serve as a platform for research instruction. However, at UCF Subject Librarians also are using them as an innovative way to market new resources and services and to assist users in finding alternative sources when the library is not able to provide the exact content being requested. Frequently the Subject Librarians create LibGuides that serve as step-by-step instructions for using particular databases or digital collections. They publicize the URLs for these guides on bookmarks, instruction handouts, newsletters, or in web-based course syllabi.

One of UCF Libraries' most heavily used LibGuides is entitled: "Textbooks, Textbook Alternatives \& Course Readings from Library Resources" (http://guides.ucf.edu/textbooks).

This particular LibGuide encourages academic faculty to utilize library owned e-book content for their assigned class readings as an alternative to expensive print textbooks. The introduction of this Lib Guide states: "UCF Libraries offers thousands of full text online books that can be used in the classroom or by individual students to supplement class readings. Please contact your Subject Librarian for help with incorporating the books into your syllabi."

This LibGuide goes on to list each of the online book databases to which UCF Libraries subscribes, with a listing of each subject area covered by the database and the number of titles included for each subject area. For example:"the Sage e-books digital collection offers a total of 16 disciplines, with 604 e-books in the Business and Management section, 999 e-books in the Sociology section" and so on. LibGuides such as this are very helpful to faculty who are interested in using digital collections for their class readings because they provide specific information about the resource and are ideal for marketing library resources. Links to general and subject specific
LibGuides can easily be placed in regular Subject Librarian-authored newsletters to faculty.

\section{Subject Librarian Engagement in the Academic Community}

At UCF Libraries there is a new emphasis on Subject Librarians becoming more mobile. Subject Librarians are getting out of the library building and spending quality time visiting their assigned academic departments and individual faculty members. They are meeting with student clubs and associations throughout campus. The Subject Librarians use these opportunities to introduce their faculty and students to new and under-used digital resources and to demonstrate how these resources can be used to assist with their teaching and research. Publisher sponsored events including the one with T\&F attract faculty members who may have little previous interaction with the library thus setting up new opportunities for librarians to later meet them in their offices to discuss ways the library can contribute to teaching and research.

\section{Subject Librarian Training}

The Research and Information Services and Acquisitions and Collection Services Departments are working together to provide training for the Subject Librarians to support them in their digital resource marketing role. The Research and Information Services Department coordinates annual all-day reference retreats, monthly reference meetings, and an online "Subject Librarian Toolkit" Lib Guide http://guides.ucf.edu /subject-librarian-toolkit to support the Subject Librarians in marketing digital resources.

The Acquisitions and Collection Services Department works closely with UCF Libraries' many vendors to coordinate frequent publisher training workshops for librarians and academic faculty that focus on new or under-utilized resources. Having close relationships with publishers and the academic community helps to improve the success of marketing library resources. 


\section{Measuring the Success of Subject Librarian Marketing of Digital Resources}

Success is measured by evaluating the overall impact of the Subject Librarian model on resource utilization. Does the Subject Librarian marketing role promote the desired return on investment for expensive library digital collections? Do librarians feel more engaged with academic faculty? Are Subject Librarians given time to speak at university and academic department meetings and to distribute information about the Libraries' new resources and services?

The important interaction between dedicated Subject Librarians and appointed academic department representatives remains at the heart of this new resource marketing initiative. The development of positive, trusted relationships with academic departments, faculty, and students is the foundation for all marketing initiatives.

Looking ahead to the future, the success of this new Subject Librarian digital resource marketing model will be measured by:

- An increase in Subject Librarian outreach to academic departments, faculty and students.
- An increase in academic faculty participation in collection development.

- An increase in faculty-student-librarian use of the libraries' digital resources (as shown by the number of hits and downloads each resource receives).

- More informed collection development that will lead to even stronger collections and more effective use of UCF Libraries' limited materials budget.

The new emphasis on marketing has provided UCF Libraries with an opportunity to succeed in new ways and to develop stronger ties with UCF academic programs, departments, faculty and students. The aforementioned efforts to collaborate with T\&F resulted in increased efforts to reach out to other publishers to provide more training to librarians, and to raise awareness of new resources with librarians and faculty. Finally, the emphasis on collaboration with publishers and faculty has also inspired a stronger sense of cooperation between two departments at UCF, Acquisitions and Collection Services and Research and Information Services. Together these departments are finding new ways to work together to improve library resources and make a positive impact on the teaching and research mission of the University of Central Florida. 